\title{
Round Table at San Remo
}

The International Institute of Humanitarian Law held its ninth Round Table and Red Cross Symposium from 7 to 10 September in San Remo. This annual meeting has become a tradition and was attended this year, as in previous years, by a large number of leading figures from the international humanitarian institutions, as well as legal experts interested in humanitarian law and the law relating to refugees, representatives of National Red Cross and Red Crescent Societies, members of university faculties and other experts. The ICRC delegation was made up of Mr. Alexandre Hay, President of the ICRC, Mr. J. P. Hocké, Director for Operational Activities, Mr. J. Moreillon, Director for General Affairs, and a number of other members of the ICRC staff.

The Round Table was opened by the President of the Institute, Professor J. Patrnogic, and the participants were then divided into two study groups.

Group I, under the chairmanship of Professor Frits Kalshoven of Leiden University (Netherlands), studied the relations between customary law and Prococol I additional to the Geneva Conventions of 1949, with particular regard to Part III (Methods and means of warfare, combatant and prisoner-of-war status) and Part IV (Protection of the civilian population). The members of this group examined the often misunderstood corpus of rules of customary law. They were unanimous in their assertion that customary law is universally recognized and underlies all the subjects discussed. In their discussions, emphasis was laid on the important fact that, especially in the field of protection of the civilian population against the effects of hostilities, Protocol I does not, in the main, introduce any new and independent rules of law. On the contrary, it is a codification of customary law, which it expands, without detracting from various opinions on the scope of one or other of the rules of customary law.

Study group II was under the chairmanship of Dr. Ahmed Abu Gura, President of the Jordanian Red Crescent and Chairman of the Standing 
Commission of the International Red Cross. This group's varied programme began with a discussion on « The Red Cross and human rights ", which was introduced by Mr. J. Moreillon. Mr. R. Kosirnik of the ICRC's department of Principles and Law then read a paper on « Red Cross activities to aid refugees ». This constituted an initial response to Resolution XXI of the twenty-fourth International Red Cross Conference (Manila, 1981). Group II also heard a report on "Current problems encountered in the protection of refugees" by a representative of the High Commissioner for Refugees.

The large numbers attending the Round Table in San Remo reflect the specialists' constantly growing interest in these meetings, where not only legal questions but also matters arising from Red Cross policy in general are subjected to debate on a very high level. 